\title{
La valoración del gótico en la estética del siglo XVIII
}

\author{
por JOSE MARIA DE AZCARATE \\ Catedrático de la Univereidad de Madrid
}

Sorprende ciertamente la casi absoluta ausencia de nombres españoles en la reciente y excelente obra de Frankl sobre el gótico. ${ }^{1}$ Sorprende que en ella no se registren, al menos, los nombres de los autores que en el siglo XVIII anticipan indudablemente el cambio que en la consideración del gótico da paso a la actitud romántica. Quizás esta ausencia de nombres españoles sea debida -como en tantas otras ocasiones- a la carencia de estudios previos sobre el tema, pues aparte de las páginas que le son dedicadas en la clásica Historia de las Ideas Estéticas en España, de D. Marcelino Menéndez Pelayo, sólo la Revista de Ideas Estéticas ha dedicado algunas páginas a esta materia. ${ }^{2} \mathrm{Al}$ mismo tiempo, nos animan a escribir estas líneas, incompletas a todas luces, las frases que,

1. Paul Frankl: The Gothic. Literary sources and interpretations through eight centuries. Princeton, 1960 .

2. M. Menéndez Pelayo: Historia de las ideas estéticas en España, C. S. I. C., Madrid, 1947, t. III. Ricardo del Arco: aJovellanos y las Bellas Artes», Rev. Ideas Estéticas, 1946, p. 31.

También sobre Jovellanos: Fortunato de Selgas: «Jovellanos, considerado como crítico en Bellas Artes», Revista de España, 1883, ts. 91 y 92, ps. 467 y 92. 
justificando su encomiable obra, dedicaba en 1804 D. Isidoro Bosarte al afán, tantas veces fallido, de demorar para un futuro la publicación fragmentaria de los aspectos de un problema:

"Las bellas artes necesitan historia propia. Ellas son una parte esencial en la gloria del talento humano, y su utilidad es notoria a todos. Pero, ¿por qué razón no se ha llegado a escribir todavía la historia de las bellas artes en España? Acaso será por aquélla, que es como proverbial entre los literatos extranjeros quando en elogio de los historiadores españoles dicen: Los españoles no escriben sus historias sino quando tienen ya juntos todos los materiales. Juntar primero todos los materiales es nuestro genio nacional...» (G., p. III).$^{3}$

Pues, en efecto, a veces no se tiene presente que las aportaciones incompletas pueden ser la base de una consideración ulterior exhaustiva, o el fundamento y acicate para trabajos más completos.

Es sabido cómo en España, en la práctica, la etapa contraria al gótico no tuvo una aceptación total. Baste citar la construcción de obras conforme a las estructuras góticas a todo lo largo del siglo xVI, como ya en

3. Para este trabajo se han utilizado fundamentalmente los siguientes textos, que citaremos con iniciales:

(A) P. Benito Gerónimo Feijoo: Teatro, tomo III, Discurso 10: Amor a la Patria y Pasión Nacional; tomo IV, Discursos 13 y 14: Glorias de España (B.A.E., t. 56, págs. 141 y 194).

(B) Idem., Madrid, 1765, tomo VI, Discurso 11: Razon del gusto, págs. 408-423.

(C) Idem., Discurso XII: El ano sé qué», págs, 424-439.

(D) Opere di Antonio Raffaello Mengs... pubblicate da F. Giuseppe Niccola D'Azara. Parma, 1780. Lettera di Antonio Raffaello Mengs ad un Amico sopra il Principio, Progresso e Decadenza dell'Arte del Disegno.

(E) Idem., Frammento di un discorso sopra $i$ mezzi per far fiorire le belle Arti in Spagna.

(F) Antonio Ponz: Viaje de España. Madrid, 1947 (Ed. de 1787).

(G) Isidoro Bosarte: Viage artístico a varios pueblos de España..., tomo primero: Viage a Segovia, Valladolid y Burgos. Madrid, 1804.

(H) Isidoro Bosarte: «Discurso sobre la restauración de las Bellas Artes en Españas, Gabinete de Lectura española, Madrid, núm. 2,

(I) Isidoro Bosarte: «Disertación sobre el estilo que llaman Gótico en las obras de Arquitecturas, Gabinete de Lectura Española, Madrid, núm. III.

(J) Isidoro Bosarte: Observaciones sobra las Bellas Artes entre los Antiguos hasta la conquista de Grecia... Parte segunda. Contiene las observaciones de la Pintura entre los Griegos. Madrid, 1791.

(K) Idem., Parte Tercera. Obsarvaciones sobre la Arquitectura entre los griegos. Madrid, 1791.

(L) Idem., Parte Quarta. Contiene las observaciones sobre las Bellas Artes entre los Antiguos Egipcios. Madrid, 1791.

(M) Gaspar Melchor de Jovellanos: Elogio de las Bellas Artes pronunciado en la Academia de San Fernando (14 jull. 1781), B. A. E., tomo 46

(N) Idem: Diario Segundo (1791). B. A. E., t. 85

(O) Idem: Diario Cuarto (1792). B. A. E., t. 85

(P) Idem: Diario Sexto (1795-1796), B. A. E., t. 85.

(Q) Idem: Elogio de Don Ventura Rodrtguez (19 enero 1788). B. A. E., t. 46.

(R) Idem: Cartas a Don Antonio Ponz (1782-1792). B. A. B., t. 50.

(S) Idem: Memoria del castillo de Bellver. Apéndice I a la descripctón histórico-artistica del castillo de Bellver. Apéndice segundo. Memoria sobre las fábricas de los conventos de Santo Domingo y San Francisco de Palma. B. A. E., t. 46.

(T) Idem: Descripción panorámica del castillo de Bellver (5 mayo 1805). B. A. E., t. 87.

(U) Idem: Sobre la Arquitectura inglesa y la llamada gótica (Bellever, mayo 1805). B. A. B., t. 87. 
el siglo xvirr reconocía el propio Bosarte al considerar la persistencia de las formas góticas en nuestro peculiar Renacimiento:

«Basta notar ahora que el Real Monasterio del Escorial en España fue para nuestras artes lo que la Iglesia de San Pedro en Roma para las de Italia» $(H .$, p. 5).

Aun en el siglo xvir son numerosísimas las capillas que se erigen y cubren con bóvedas de crucería, y todavía en pleno siglo xvIII, por ejemplo, las estructuras góticas dan su especial fisonomía a la iglesia de Santa María de San Sebastián.

En el campo más libre y docto de la teoría estética, baste recordar, paralelamente, los elogios en el siglo xvi de los templos góticos, como, por ejemplo, la poética descripción de la Catedral de León, en 1586, por Pedro La Vezilla, ${ }^{4}$ y ya en 1681 la utilización por Simón García de las notas de Gil de Hontañón, de evidente utilidad práctica, como se deduce del propio hecho de su aprovechamiento. ${ }^{5}$ Ciertamente que esta persistencia en la práctica de las estructuras góticas no supone una excepción hispánica; pues conocidas y estudiadas recientemente lo han sido en los edificios góticos franceses y flamencos, por ejemplo..$^{6}$ Aun en escritores que representan el polo opuesto en la consideración estética, como el barroco Caramuel, se vislumbran los implícitos elogios, cuando escribe: «Es verdaderamente curiosa y ingeniosa la gothica; y difficultosa si se ha de labrar bien»; y, más adelante, al referirse a los complejos soportes góticos, formados por múltiples baquetones,

«se divierten los ojos con una proporcionada variedad, que para ser bien executada, pide que con gran ingenio, y no $\sin$ gran cuydado y advertencia se proceda en sus cortes».

No obstante lo cual, no impide que al fin estime que tanta complejidad no deja de ser un esfuerzo baldío, porque:

«ésta es en summa la Architectura Góthica, que es muy difficultosa, si se ha de hazer bien hecha y después de bien executada y trabajada, no es hermosa».?

En la primera mitad del siglo xvirr, en plena exaltación del rococó, se inicia en el campo del espíritu la reacción que ha de desembocar en

4. Pedro La Vezilla: Primera y segunda parte de El León de España. Salamanca, 1586, Canto XXIX, folios $362-365$.

5. Compendio de Architectura y simetría de los templos, por Simón García. Año de 1681. Publicado por José Camón. Salamanca, 1941.

6. P. Heliot: aLa fin de l'architecture gothique dans le nord de la France aux XVIIe et XVIIIe siècles». Bultetin de la Commission royale des monuments et des sites. T. VIII, 1957.

7. Caramuel: Architectura civil, recta $y$ oblicua. 1678. 
el neoclasicismo racionalista. Pero es claro que en esta primera mitad del siglo XVIII se ponen las bases también de un neoclasicismo subjetivo, que por lo que tiene de evocación de la Antigüedad en esencia constituye una fase del Romanticismo. Por otra parte, la reacción frente a las libertades del inmediato barroquismo churrigueresco o respecto a los excesos decorativos del rococó centroeuropeo, si de una parte puede justificar el deseo de entroncar con la Antigüedad, que fue la fuente del Renacimiento, bien pronto se advierte que la actitud respecto al pasado medieval, merced al transcurrir del tiempo, ha de ser muy diversa.

En efecto, si en el Renacimiento la vuelta a las formas y espíritu del mundo clásico se ofrece como una ruptura obligada con el pasado inmediato, que es lo medieval, y aun así no se consigue plenamente, es claro que ahora el puro neoclasicismo no podría triunfar en el campo del espíritu, cuando el conocimiento del mundo medieval era más profundo y por la mayor antigüedad de los monumentos medievales ofrecen una cierta atracción. Si ya el Renacimiento, como solución de continuidad respecto a la Edad Media, había encontrado fuertes resistencias en los países con un pasado medieval de importancia, más fuertes han de ser estas resistencias ahora que se propugna la vuelta al racionalismo vitrubiano. Por otra parte, en la reacción frente al barroquismo, es decir, contra el pasado, para dar paso a una renovación del clasicismo, se percibe bien claramente que es preciso hacer una distinción. Una cosa es el barroquismo como degeneración del arte clásico, y otra los estilos medievales que se ofrecen la mayor parte de las veces no como una degeneración de lo clásico, sino como una cosa diferente. Fruto, a lo sumo, de una violenta ruptura con la Antigüedad determinada por la desaparición de la cultura antigua, en el Imperio desintegrado, que obliga a los pueblos europeos surgidos al alborear la Edad Media a buscar nuevas formas, para lo que han de inspirarse en la naturaleza o en las formas del arte del Mediterráneo oriental. Era, por tanto, el arte medieval no el fruto consciente de una degeneración del gusto, sino la consecuencia de la ignorancia y la destrucción de la Antigüedad en Occidente. Entonces se buscó un lenguaje expresivo, conforme a los medios y posibilidades de que se disponía, por lo que evidentemente tenía atisbos positivos que le justifican y eliminan las acerbas críticas, pues, al fin y al cabo, este arte medieval era el fruto consciente y expresión del deseo de luchar contra la ignorancia en que se había sumido Europa, en un mundo bárbaro y desorientado que no estaba al alcance de comprender los restos del mundo antiguo.

En este sentido la actitud frente a todo el arte medieval no puede llevar implícita necesariamente la crítica negativa, sino que, como ocurre 
respecto a las artes exóticas, ha de considerarse como algo fundamentalmente ajeno, en el que el hombre del siglo XviII encuentra muchas cosas plausibles e incluso imitables, aunque siempre ha de reconocerse la superior calidad del arte clásico.

Coadyuva evidentemente a esta consideración desapasionada del arte medieval, la crítica acerba que se hace del pasado inmediato, es decir del estilo Barroco o más bien del Rococó, pues repetidamente hemos de ver en los estilos artísticos cómo la actitud contraria al pasado polariza la atención hacia lo inmediatamente anterior, punto de arranque de la reacción enlazando a veces, saltando a través del ayer, con las etapas anteriores.

La actitud conciliadora respecto a lo medieval se encuentra ya, por por ejemplo, en los Discursos o ensayos de Feijoo, singularmente en los titulados "Amor de la Patria y Pasión Nacional» $\mathrm{y}$ «Glorias de España» y así en este último leemos:

«Aquel ejemplo me he propuesto seguir en este discurso, cuyo asunto es mostrar a la España moderna la España antigua; a los españoles que viven hoy, las glorias de sus progenitores; a los hijos, el mérito de los padres; por que, estimulados a la imitación, no desdigan las ramas del tronco o raíz. De lección de un siglo a otro siglo" $(A)$,

pues como escribe Sarrailh: «La evocación de la «España Antigua», aparece en gran número de escritores, que alaban el pasado patrióticamente frente a la «España moderna»." Parece claro que si el pasado inmediato había sido el reinado de Carlos II, no es lógico estimar que esta lección en cuanto a lo estimable podía ser tomada de este inmediato ayer. Por otra parte, esta evocación del pasado medieval, que está latente y vigente en toda nuestra literatura manierista y barroca, ${ }^{10}$ fácilmente habría de desembocar en el sentimiento evocador del pasado, que ya aflora de forma clara en las obras de Jovellanos, lo que hace decir a Angel del Río, al referirse a la descripción del Castillo de Bellver, de 1805 :

«En ningún otro instante se dejó penetrar el alma de Jovellanos de sentimiento más hondo ni alcanzó su expresión un vibrar de vida tan

es de extrañar que haya quedado poca memoria de tantos hombres 作

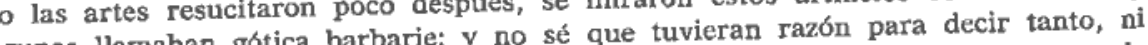
educados en la que algunos llamaban gotica barane cosas se ven hoy hechos de entonces, y aun de para medirlos todos con una misma medida, porque cosas las han igualado en sus mejores partes» antes, de mucha admiración, y que poco después pocos las han igualado en sus mejors $(F, 1,2,29)$.

9. Juan Sarrailh: La España ilustrada de la segunda mitad del siglo XVIII. México, 1957.

10. Francisco López Estrada: Introducción a la literatura medieval española, 2.8 ed. Madrid, 1962. páginas 244 y ss. 
intenso como cuando recrea en su imaginación las fiestas caballerescas y poéticas..., o cuando, atalayando desde sus ventanas las campiñas mallorquinas... Evocación medieval, un sentido moderno del paísaje, balbuciente todavía, pero con todos los caracteres ya de la visión romántica. „11

\section{Según Menéndez Pelayo no se puede pedir a Ponz}

«el espíritu de amor a la Edad Media que ha sido en nuestro siglo el despertador y acicate de la brillantísima generación de arqueólogos románticos»,12

pero es claro que el solo hecho de prestar atención tan cuidadosa al arte medieval indica un indudable aprecio y consideración. ${ }^{13}$ De la misma manera que, aparentemente, Bosarte adopta una actitud negativa respecto al arte medieval, no obstante lo cual, en su «Disertación sobre el estilo que llaman gótico en las obras de Arquitectura», se le escapa una paladina afirmación de su inconsciente aprecio, al margen de lo que su concepción intelectual le obliga, y escribe:

«De aquel estilo no quedan teatros, ni anfiteatros... Esto hace pensar poco favorablemente en la edad media, cuya memoria por otra parte nos embelesa muchon (I., p. 47).

Dualidad respecto al gusto y al concepto intelectual que, como veremos, se acusa también en Jovellanos, como advirtió ya Ricardo del Arco. ${ }^{14}$

Uno de los factores que más han de influir en la apreciación del gótico y del arte medieval en suma, es el determinado por el giro o matiz que en las razones de las apreciaciones estéticas se exponen con claridad frente al racionalismo conducente a un rígido neoclasicismo, en obras como la del P. Feijoo. En su discurso sobre "Razón del gusto», desarrolla la tesis de la bondad del gusto, desde el momento que es deleitable para quien lo aprecia, pues

"Ser gusto, y ser malo, es implicación manifiesta, porque sería lo mismo que tener bondad delectable, y carecer de ella» $(B$.$) .$

Ahora bien, si ciertamente en lo que el gusto es motivado por la aprehensión es educable o reformable, conforme a la razón, no lo es tanto 1945-46

11. Jovellanos: Obras escogidas, edición, introducción y notas de Angel del Río, C. C., Madrid,

12. Menéndez Pelayo: ob. cit.

13. Asl, Ponz escribe: «Las tales pinturas primitivas... tienen, acaso, tales expresiones y partídos o están hechas con tal prolijidad y hermosura de colores, que no pocos de los profesores que hoy las imitar ( $\left.F, I_{2}, 29\right)$ tendrfan bien que hacer si en las buenas partes que he referido las quisiesen

14. Ricardo del Arco: art, cit. 
en cuanto es motivado por el temperamento. De aquí se deriva necesariamente la libertad y variedad en el gusto inexplicable a veces desde el punto de vista de la razón, aspecto que desarrolla en su Discurso sobre "El no sé qué».

\section{En efecto, indica el P. Feijoo como}

«en muchas producciones, no sólo de la Naturaleza; más aún del Arte, encuentran los hombres, fuera de aquellas perfecciones sujetas a su comprehensión, otro género de primor misterioso, que quanto lisonjea el gusto, atormenta el entendimiento; que palpa el sentido, y no puede descifrar la razón; y ansí, al querer explicarle, no encontrando voces, ni conceptos, que satisfagan la idea, se dexan caer desalentadas en el rudo informe, de que tal cosa tiene un no sé qué, que agrada, que enamora, que hechiza, y no hay que pedirles revelación más clara de ese natural mysterion $(C$.).

En razón de lo cual llegamos a encontrar belleza en lo que desde el punto de vista racional es claramente imperfecto, pues

«entran en un edificio, que al primer golpe que da en la vista, los llena de gusto, y admiración... Si les preguntan qué hallan de exquisito o primoroso en arte, responden que tiene un no sé qué que embelesa» (C.),

por lo que puede estimarse, que posee

«una gracia oculta ,indefinible, que no está sujeta a regla alguna», o más bien "una determinada proporción de las partes" $(C)$

en que no se había pensado y distinta de la que se tiene por única.

Esta apreciación nos ha de conducir a indagar qué otras perfecciones artísticas pueden darse al margen de las reglas dadas por el arte clásico, pues como más adelante explica:

«De suerte que Dios, de mil maneras diferentes y con innumerables diversísimas combinaciones de las partes, puede hacer hermosísimas caras. Pero los hombres, reglando inadvertidamente la inmensa amplitud de las ideas divinas por la estrechez de las suyas, han pensado reducir toda la hermosura a una combinación sola o, quando más, a un corto número de combinaciones; y en saliendo de allí, todo es para ellos un mysterioso no sé qué» (C.).

Ideas que, a poco que se piense, han de conducir a la estimación de todos los estilos que se estimen independientes del arte clásico, ya que no se ofrecen como una degeneración de lo que se estima perfecto.

No obstante, estas ideas han de abrirse camino con lentitud, pues en principio, en plena exaltación y justificación del incipiente neoclasicismo, la actitud es negativa respecto a todo lo anterior como expresión 
de un ardiente racionalismo. Así, para Mengs, el gótico es el fruto de una imitación sin regla de los edificios antiguos, interpretados burdamente por la ignorancia bárbara:

"Quando finalmente si perde la stima delle Belle Arti nell'Imperio Romano... venne il tempo, que conosciamo sotto il nome di Architettura Gotica... volendo imitare senza regole gli edifizi antichi, ch'eglino stessi rovinavano... trascuravano lo studio del buongusto, e delle belle proporzioni... e mettendo tutto il merito nella difficoltà, e nell'arditezza, e non nell'eleganza, scapparono in quelle Nazioni quelle tanto stravaganti, e rare cose totalmente contrarie al buon gusto, e alla ragione» (D., ps. 128-129).

Barbarie de la que no quedó exenta España, ya que sus habitantes fueron bárbaros, y luego las oleadas de los pueblos germánicos y de los moros acabaron por arruinar «le poche relique di cultura che avean potuto lasciarvi i Romani... e mancando in oltre esempi di Buongusto si diedero a imitare il Gotico, e il Moresco» (E. ps. 213-214).

Del mismo criterio negativo participa Bosarte, que, no obstante, como ya hemos indicado, lucha entre sus conceptos mentales y lo que le dicen los sentidos. Así son frecuentes los juicios antinómicos entre lo que afirma en un lado y lo que dice en otro. Así afirma: "Vuelvo a decir que todo el goticismo artista (séame lícito usar esta voz) era un estado tenebroso" $(H$.$) , y también: "En la pintura y escultura el goticismo no$ tiene ni sistema ni disculpa» (G., pág. 42), por lo que estima que en las restauraciones y adiciones debe mantenerse el criterio de hacerlas conforme al «buen gusto» y no al gótico, por varias razones, entre ellas,

«5. Las añadiduras según el buen gusto greco-romano a las obras góticas no pueden perjudicarlas, ni desgraciarlas, por quanto son mejores que ellas. 6. En añadiendo nuevas obras al gótico, irá renaciendo el edificio según el buen arte. 7. Por la inmitación del estilo gótico no hay más razón que la conformidad con una cosa mala» (I., ps. 51-52).

E, incluso, cuando se refiere a obras concretas, valga el ejemplo del retablo de la Vera Cruz de Segovia, si dice que «su execución es de la suma imbecilidad del arte», y "todo es de aquella mezquindad que caracteriza el tiempo tenebroso que precedió al renacimiento de las artes», no obsta para que elogie su técnica, pues, «si se tiene cuidado con ellas, durarán siglos sin decadencia, para afrenta de la pintura al olio o aceyte de linaza" (G., p. 46); y, si también estima que en la escultura "fueron miserables", no deja de reconocer que «en algunas estatuas del estilo gótico se ven algunos buenos partidos de paños»(G., p. 46), llegando a dedicar cálidos y significativos elogios al gran escultor gótico Sebastián de Almonacid por su obra en el Parral de Segovia: 
"No puedo olviđar al escultor de Torrijos Sebastián de Almonacid, acreedor ciertamente a haber nacido un poco más tarde. ¡Qué velocldad inconcebible la de la mano de este hombre.... No podemos decir que la negligencia en el trabajo favoreciese a la celeridad, porque la Virgen está muy concluida, y es hermosa» (G., ps. 57-58).

Realmente, lo que Bosarte lamenta es justamente la falta de reglas, base de todo academicismo; como cualquier crítico contemporáneo, al enjuiciar las nuevas tendencias, reglas que, una vez halladas, justificaria, desde el punto de vista racionalista del neoclasicismo, cualquier estilo. Así, escribe :

«...se ve como una noche cargada de tinieblas. A cada paso se podía errar. No habia máximas seguras y ciertas que produxesen la elegancia, el buen sentido, y la perfección de las obras" ( $H .$, p. 1$)$.

Paralelamente Jovellanos se pronuncia de análoga manera, pues, al indicar cómo en la pintura y escultura góticas se encuentran rasgos de ingenio que sorprenden, nobleza, gentileza y expresividad, se lamenta de que sno nos ofrecen la idea de otra proporción que la que determina el ojo del artistan, lo cual era debido a la carencia de un sistema fijo y seguro de proporciones, por lo cual «sus progresos, tales cuales fuesen, nunca podian llevarles hasta la perfección» ( $M .$, ps. 352-353), lo cual no obsta para que, ya que el artista «buscaba afanosamente la belleza», las artes góticas, aunque imperfectas, "no por eso (son) indignas de la especulación de los aficionados» (M., p. 353).

Es evidente que en los escritores del último tercio del siglo xviII se advierte una evidente tendencia valorizadora del gótico, que tiene lugar, por tanto, en pleno triunfo del neoclasicismo. En efecto, si en un edificio estimamos como fundamento de su belleza la solidez, la adecuación para el fin a que se destina, la tendencia a ennoblecer las formas utilitarias elevando el espíritu al conseguir la belleza, y la economía, preciso es ver cómo en estos escritores del siglo xviII únicamente encuentran un resquicio para su crítica al considerar el aspecto económico de las obras góticas.

Ante un edificio gótico el primer movimiento que se produce en el ánimo del contemplador es el de admiración, antes de entrar en el racional examen de sus formas. En efecto, hojeando a Ponz, surgen las frases admirativas por doquier. Así, al hablar de la catedral de Toledo, escribe:

"Este es el edificio que hoy se ve y todo el mundo admira por su grandeza, solidez y por los adornos que lo hermosean... La arquitectura de este templo es lo que comúnmente llamamos gótica, en la cual 
he tenido siempre mucho que admirar, considerando su buena proporción en aquel estilo, su firmeza, lo gentil de sus miembros y sus adornos, con ser todo tan diverso de los principios que en Grecia e Italia se encontraron..." ( $F$., I, 2, 9-11),

De la misma manera, califica de "fábrica verdaderamente magnífica» a la Lonja de Palma de Mallorca, calificativo que repite constantemente al enjuiciar los monumentos góticcis. Aun, incluso, Bosarte, a pesar de su consciente oposición a las formas góticas, escribe: «Magnífico es el alcázar de Segovia, y una de las obras más vistosas del estilo gótico en la arquitectura» (G., p. 46), prodigando sus elogios en forma altamente encomiástica cuando se enfrenta con las torres y fachadas de la catedral de Burgos, particularmente por la extraordinaria blancura de la piedra de las canteras de Hontoria, «tan blanca como la misma nieve», de tal pureza, que

"un edificio de piedra ontoria no puede mirarse en muchos años después que se ha hecho sin lesión de la vista. Tal era la sensación que debería causar el aspecto de este edificio en los siglos pasados» (G., páginas 258-259).

Igualmente Jovellanos repite constantemente los adjetivos laudatorios cuando se refiere a obras góticas, y así escribe de la catedral de Burgos, "grande, magnífica..., magnifica capilla gótica del Condestable» ( $P$., página 255). Quizá más característica sea su exaltación poética al referirse a la belleza de la catedral de Palma de Mallorca, en un verdadero arrebato lírico, en el que, no hallando la razón de la belleza que le cautiva, recurre al característico no sé qué para explicarla:

* Mas, a pesar de que estas faltas de euritmia y de una forma tan extraña prometen poco favorable efecto, el que produce el todo de esta obra, sin ser bello ni elegante, tiene un no sé qué de grande y majestuoso que sorprende y agrada notablemente a la vista.»

continuando en tono laudatorio ensalzando estas «obras gigantes», en las que la profusión de la escultura contribuye con

"la grandeza de la arquitectura para realzar sus sublimes gracias y poner en noble competencia el genio de los artistas» ( $T$., ps. 360-361).

Así, en la obra de Jovellanos se repiten los elogios a los edificios góticos. Estima como bellísimas las vidrieras de la catedral de León, que por su arquitectura, uen nuestro dictamen, sobrepuja a todas las de Europa en belleza: (Q.) De la misma manera elogia los monumentos góticos de Palma de Mallorca, particularmente el castillo de Bellver, «la belleza del todo es grande y digna de ser más conocida (S.), y la Lonja: 
«la hermosa fábrica de ..., este noble edificio..., tan bello plan..., a Sagrera, y no a otro, pertenece toda la gloria librada a su belleza..., la continuación de este edificio bajo un plan tan bello y magnífico, que así prueba el genio del artista»(S.).

Juicios tan explícitos de su admiración por la arquitectura gótica habían de desembocar lógicamente en la exaltación de este estilo medieval a la altura del arte clásico y aún más, con lo que ya en la obra del propio Jovellanos se da paso a la actitud romántica respecto al pasado, es decir, a la preferencia de nuestro pasado medieval, concreto a una nacionalidad, frente al sentido universal, ecuménico, del arte clásico. Así, Jovellanos, en su ensayo sobre la arquitectura gótica, después de analizar los posibles orígenes de las formas góticas, escribe:

«A este fin. modificando unas, desfigurando otras. combinándolas todas y reduciéndolas a unidad, completaron aquel sistema de arquitectura, que por su novedad, su osádía y rica gentileza, puede competir con la de Roma y Grecia y llenar de orgullo al genio de la Europa» (U., ps. 376-377).

En el análisis de los monumentos góticos se encuentran valores positivos entre los que se sitúa como uno de los esenciales el de su perfección técnica, que permite la erección de estos sorprendentes conjuntos, cuya osadía y magnífico estado de conservación, después de tantos siglos, causan admiración. Así, Ponz califica de «excelente construcción» la catedral de Plasencia, y, al referirse a la catedral de León, escribe:

«Muy bien se puede decir que, en su género gótico, es una de las cosas más particulares que pueden verse, atendiendo a su gentil y delicada construcción, a la finura de sus ornatos, y, sobre todo, a su fortaleza, junta con tan poco espesor de paredes, que parece milagro puedan mantener la gran máquina» $(F ., \mathrm{XI}, 6,31)$.

La misma claridad refleja lo que escribe respecto a la catedral de Burgos:

"No se puede ver cosa que alegre tanto la vista desde alguna distancia como el edificio de la catedral, obra sumamente delicada, trepadas sus torres y ornatos del cimborrio, como si fueran una filigrana, y al mismo tiempo fortísima, como se reconoce examinando el edificion (F., XII, 2, 9).

En la misma línea Bosarte, después de considerar que la arquitectura gótica «viene a ser, según la opinión común, una depravación y corrupción de la arquitectura antigua greco-romana", estima que una de las razones fundamentales de haber prevalecido durante siglos «sin dexar levantar cabeza a la antigua» es "que la arquitectura gótica llegó a combinar la ligereza con la solidez» (G., ps. 39-40). Y es curioso que el 
propio Bosarte, que reconoce la habilidad técnica de los arquitectos góticos, únicamente encuentre base para su crítica en la carencia de "entusiasmo poético», lo que no obsta para que reconozca la admiración que le produce la "osadía y animosidad de los arquitectos góticos» y alabe la belleza de la torre de la catedral de Viena, pues,

asiendo sutilisima en muchas de sus partes, resiste no sólo el ímpetu de los vientos..., violentos y continuos, sino que también sufrió la prueba del bombardeo de los Turcos en el asedio de aquella Ciudad" (I., pá-
ginas 43.44).

Osadía, destreza técnica, fortaleza, que también es cumplidamente elogiada por Jovellanos, en especial en su poética descripción del castillo de Bellver.

Este reconocimiento de la buena técnica de la arquitectura gótica se enlaza con la apreciación de los efectos de grandiosidad y de elegancia, que producen los grandes y pequeños edificios góticos. Ponz, respecto a la catedral de Toledo, dice: "...éste es el edificio que hoy se ve y todo el mundo admira por su grandeza.... (F.), y de la iglesia de San Benito, de Valladolid, escribe: "La iglesia es espaciosa..., de un gótico grandioso, sin faltarle la majestad conveniente en esta línea» (F., XI, 3, 56). Grandiosidad majestuosa que imprime solemnidad a los interiores góticos, como reconoce Ponz respecto al interior de la catedral de León:

"No puede usted creer qué seriedad y majestad resulta y se concibe de esta primera ojeada, y es que no hay retablos, retablitos ni otros objetos mezquinos en el cuerpo de la iglesia, sino que se elevan las paredes de las naves colaterales con vidrieras desde arriba abajo» (F., XI, 3, 32).

Por el contrario, Bosarte intenta introducir una distinción entre el sentido de grandiosidad y el de magnitud, con evidente tendencia a menoscabar la impresión que producen los edificios góticos; y así, respecto a la catedral de Burgos, escribe: "La catedral es una de las más suntuosas de España y de las de primera magnitud» (G., p. 257), texto a primera vista inocuo, que se aclara a la luz de lo que escribe en su Disertación sobre el estilo gótico, en donde especifica que los arquitectos góticos "confundieron la idea de la grandiosidad con la de magnitud, que son cosas muy diferentes y distintas... No es lo mismo ser grande una obra que ser grandiosa» ( $I$, p. 29). Distinción evidentemente forzada y que claramente se opone al texto de Capmany, recogido por Menéndez Pelayo: "Todos los templos góticos tienen siempre un aire de grandiosidad, aunque no sean realmente grandes...»

Junto a esta apreciación de la grandiosidad del templo gótico se per- 
cibe de un lado la perfección técnica con que está hecho y, especialmente, un evidente sentido de la gentileza y de la elegancia. Ponz alaba la elegancia de la catedral de Toledo y destaca la perfección de sus partes, y así estima que la Puerta de los Leones es una "cosa perfectísima en sus líneas» $(F ., \mathrm{I}, 2,15)$, y a la magnífica capilla de Don Alvaro de Luna "la total elegancia que tendría en esta línea se la quitan dos altares de mal gusto moderno que tiene a los lados» $(F ., \mathrm{I}, 2,37)$.

El propio Bosarte, respecto a la catedral de Segovia, escribe:

"Vengamos ya a la catedral, iglesia que puede llamarse admirable entre las catedrales de Castilla. Su belleza, su alegría y la gentileza de sus miembros nos autorizan a darle esta denominación" (G., páginas, 60-61).

No obstante, en su exacerbado racionalismo, cree justificar la elegancia de estos edificios con una nimia observación que tiene cierta gracia, y escribe:

"Una de las causas de la belleza de esta iglesia, vista por dentro, es el método de la construcción de sus pilares. En ellos no se ven juntas verticales de sus piedras, sino solamente horizontales..., los pilares altos y delgados, los quales ceñidos con igualdad horizontalmente de una estrecha cinta que es la junta, habían de ser de un aspecto delicioso como así lo son» (G., p. 67).

Aunque la sinceridad de Bosarte es evidente, es preciso reconocer que desde nuestro punto de vista resulta algo extraño su peculiar gusto cuando contrapone la elegancia gótica a la greco-romana, con el elogio a las formas cuadrada y redonda, que estimo que pocos de nosotros suscribiríamos en nuestro tiempo, y así escribe:

"Si hacemos cotejo de la Arquitectura gótica con la greco-romana, hallamos que la gótica en su estilo prefería las figuras angulares y que la greco-romana insistía en las redondas y quadradas; pero como quiera que las figuras redonda y quadrada son más elegantes que las demás, resulta, como por rigurosa demostración, que el estilo grecoromano es más elegante que el gótico» $(H .$, p. 31$)$.

Concepto que no es de circunstancia, ni forzado, pues lo repite Bosarte en otros de sus escritos:

"Los Romanos formaban las letras ateniéndose a las formas quadrada y redonda, que son las figuras más elegantes de todas» (I., p. 11).

Jovellanos, con espíritu más en consonancia con el devenir de los tiempos, encuentra la razón de la gallardía y gentileza de los edificios góticos precisamente en todo lo contrario, es decir, tanto en la predi- 
lección por la forma apuntada, como en la delgadez suma de los soportes, que les da un cierto aire de ingravidez. Así entiende por

"gallardía y gentileza... aquella atrevida y extraordinaria delicadeza que, escondiendo la verdadera solidez de los edificios góticos, los hace parecer notablemente esbeltos y ligeros",

e indica cómo existe una preferencia por la forma piramidal, por los remates en punta, lo que produce "un carácter tan rico, tan ligero y gentil»(Q.).

Pero claro es que en todo tiempo, y máxime ahora, desde el punto de vista de la utilidad, obsesión del hombre de la segunda mitad del s. XVIII, la belleza y el aprecio, en suma, de un edificio ha de estar en función de su utilidad, de su perfecta adecuación al fin para el que fue hecho. $Y$ en este aspecto es evidente el aprecio que el hombre del neoclásico tuvo hacia el edificio gótico, como el más apropiado para las exigencias espirituales del hombre cristiano. Ponz se expresa con claridad:

«Esta arquitectura gótica nadie puede, con razón, decir que falta en la majestad y el decoro; al contrario, parece inventada para dárselo a los templos y casas del Señor» $(F, \mathbf{I}, 2,13)$.

Bosarte, de la misma manera, encuentra que «las funciones de iglesia y procesiones parecen bien en los edificios de aquel estilo» (G., p. 41), y, al examinar la obra de Berruguete, percibe cómo las obras de nuestro Renacimiento no suponen una cesura en la evolución artística, sino que armonizan, como culminación de las formas medievales, y escribe, al referirse al retablo de San Benito: «Da gusto ver el renacimiento de Jas artes antiguas al cubierto de bóvedas del estilo gótico» (G., p. 157). Y es paradójico señalar que, en función justamente de la utilidad y del cultivo de las artes para su eficaz desarrollo, encuentra Bosarte razones positivas que elogiar en la proliferación de tablas y esculturas en los grandes retablos góticos, costumbre laudable, pues así se mantienen muchos artistas, mientras ahora «va ya faltando ocupación de los encargos particulares» (G., p. 292).

En la misma línea y con más cálidas palabras elogia Jovellanos la adecuación de los templos góticos:

"¡Qué suntuosidad! ¡Qué delicadeza! ¡Qué seriedad tan augusta no admiramos todavía en las célebres iglesias de Burgos, de Toledo, de León y Sevilla! Parece que el ingenio de aquellos artistas apuraba todo su saber para idear una morada digna del Ser Supremo. Al entrar en estos templos, el hombre se siente penetrado de una profunda y silenciosa reverencia que, apoderándose de su espíritu, le dispone suavemente a la contemplación de las verdades eternas" (M.). 
Palabras que realmente suponen la crítica a la frialdad del templo clásico puesto al servicio del culto cristiano, y que tienen su eco en las de Capmany:

"Por otra parte, en las iglesias de estilo gótico se siente una especie de recogimiento y veneración secreta, cuya causa no acertamos a adivinar... La Arquitectura Gótica imprime cierto género de tristeza deliciosa que recoge el ánimo a la contemplación, y así parece la más propia para la soledad augusta de los templos...» (V., pág. 570).

Una veladísima crítica de la arquitectura gótica puede advertirse en la consideración de la abundante decoración de los edificios y, extrañamente, en sus relaciones con las formas de la naturaleza. Ponz no encuentra realmente inoportuna esta decoración, y así habla de los muchos ornatos agradables a la vista, ornatos que estima caprichosos: "Carece de aquellos caprichosos adornos de la manera gótica» (F., III 1, 23).

En Bosarte la crítica se expresa de forma más clara, y habla de la multitud de delgadas columnas, de la profusión de adornos, de la nimiedad del trabajo y, en fin, del

«laberinto tan intrincado de capiteles, torrecillas, pirámides, templetes, derramados sin orden $\mathrm{y}$ sin necesidad por todas las partes del templo» (M.).

Y así, si bien parece elogiar la obra de la capilla del Colegio de San Gregorio, de Valladolid, no puede evitar la crítica, teniendo presentes «los principios del arte», y así dice que

«el retablo principal de la capilla es en sus ornatos la quinta esencia de las sutilezas del goticismo, comparable sólo al sepulcro del Rey Don Juan II",

para seguir más adelante:

"Conviene mirar este retablo para ver quánto puede hacerse de prolixo quando falta el fundamento del diseño» (G., ps. 110-111).

Pero su crítica no puede ocultar la popularidad y el aprecio de la prolija decoración gótica, y así, cuando se refiere a los magníficos sepulcros de la Cartuja de Miraflores, los elogia bellamente en una imagen poética al comparar el esplendor de su riqueza con el fulgurar postrero de una llamarada, y escribe:

«Unas obras de escultura de grande expectación popular... No puede negarse que son obras de mucha prolixidad y paciencia... Las menudencias de los ornatos van al infinito... Parece que allí dio las boqueadas el goticismo, y brilló como las llamaradas de la luz que se va a apagar..." (G., ps. 272-273). 
Es significativa esta dualidad entre su pensamiento neoclásico y lo que a veces le dicta la directa contemplación de la obra de arte, y así es representativo el cotejo que hace entre la catedral de Estrasburgo y la catedral de Ulm, que llega a parecerle obra de romanos, muy superior en belleza ésta, por su menor decoración:

"Comúnmente se da la palma de las obras góticas a la catedral de Strasburgo... Yo he visto aquella catedral, y pienso que las obras grandes de aquel estilo que hay en España no ceden a la de Strasburgo..., nuestro parecer... es que el mejor edificio gótico es la catedral de Ulmo, o Ulma en el Imperio. Si aquel Arquitecto hubiese seguido la Antiguiedad tendría la Alemania su Arquitecto que oponer a Paladio en Italia, y en España a Herrera. Viniendo por el campo a la Ciudad de Ulm, parece la Catedral alguna cosa de Romanos; según la nobleza con que se enuncia desde lejos. La torre quedó sin acabar, pero el cuerpo de su coronación está en la plazuela... Lo particular... consiste en haber despreciado y desechado toda menudencia... Este carácter la constituye rival de la de Strasburgo, y opuesta enteramente en sus máximas, y en su gusto" (I., ps. 45-46).

En su deseo de profundizar más científicamente en su crítica, Bosarte intenta apoyar toda su oposición racional a la arquitectura gótica en su relación con la naturaleza. Estima que el arquitecto gótico se inspira - como debe- en la naturaleza para la creación de las formas arquitectónicas, de la misma manera que lo había hecho la arquitectura clásica o «madre». Pero el defecto del arquitecto gótico estriba en que, por ignorancia, verifica una traslación fiel, es decir, literal de las formas de la naturaleza :

«La arquitectura de crestería llegó a poner, no en translaciones obscuras, sino en imágenes puntuales, los troncos mismos de los árboles con sus nudos y cortes, como se ven en la fachada de San Gregorio de Valladolid... La crestería es alusiva a las puntas de las rocas. La torre de San Esteban de Viena, que es la catedral de la corte imperial, presenta la idea de una montaña erizada toda de puntas» (G., ps. 40-41).

La diferencia respecto al arte clásico estriba en que el arquitecto gótico — según Bosarte- carece del espíritu poético que animaba al arquitecto griego, y, como carente de él, hace una traslación inapropiada por imitar fielmente las formas de la naturaleza, con un abigarramiento confuso que le impide abstraer de la naturaleza las formas esenciales, e incluso le conduce a despreciar algunas formas bellas que están en la propia naturaleza. En efecto, la tendencia de tomar como soporte el tronco o rama del árbol, le conduce a estimar, por su altura, que el arco apropiado es el apuntado para acentuar la verticalidad, con lo que se desentendió "por tantos siglos del mejor modelo de los arcos sugerido por la naturaleza misma en el arco iris» $(I$, p. 34). Y, en cambio, 
en los soportes «despreciaron los góticos el entusiasmo y poesía que admiramos en la invención de las columnas griegas...", los cuales representaban las vigas de madera que sostenían los techos, traslación que «se debe tener por un acto de poesía, por ser una metamorfosis ideal hecha por comparación» ( $I .$, p. 31), pues, en efecto, "la imitación de los árboles como ellos son no es camino para buscar la grandiosidad». En la decoración frente a los griegos, que

«no admitieron sino cosa que tuviese una forma elegante en la Naturaleza... Estotros de la media edad o góticos se complacían en las coles rizadas, y otras legumbres embrolladas, en que no hay elegancia alguna, sino complicación, sutileza, enredo. Con estos principios no se podía caminar al buen sentido... Pusieron también en las canales que reciben las aguas llovedizas la figura humana, degradándola de su dignidad, y contrahaciéndola del modo más indecoroso y abominable... Compárense... con la circunspección de los Arquitectos paganos, que sin tener el freno de la Moral que tenemos nosotros, nunca hacían ridícula la figura humana del uno ni del otro sexon ( $I$, ps. 38-40).

No obstante lo expuesto, cuando en 1791 el propio Bosarte publica sus «Observaciones sobre el arte clásico», afirma que el goticismo «era un estado de imitación sin consulta de la naturaleza» (J., p. 32).

Para Jovellanos no es tan clara la relación de las obras góticas con la naturaleza. Critica y niega las tesis de Hall y Warbuton, que veian en las cabañas rústicas y en los propios bosques, respectivamente, el origen del gótico, siendo más explícito en su crítica a la teoría de Felibien, que estima que el arquitecto se inspira en la naturaleza misma. Según Jovellanos, si, efectivamente, en sus orígenes el arte es el fruto y la evolución artística, es decir, el progreso artístico, sus variaciones, son nico, como no se puede dudar, ¿dónde, sino en la naturaleza, existirán sus orígenes?» (U., p. 381) —, pero luego se independiza de la naturaleza y la evolución artística, es decir, el progreso artístico, sus variaciones, son el fruto del arte mismo, que se desarrolla al margen e independientemente de la naturaleza.

A esta apreciación del gótico como estilo peculiar, digno de ser imitado en algunos aspectos o, al menos, de ser apreciado, contribuyen otros factores, que, al aislarle e independizarle respecto al barroco, le preservan también de las fuertes críticas. Ahora bien, en esta consideración del gótico, aunque en menor grado, se incluyen también los restantes estilos cristianos medievales, pues en principio no se distinguen, señalándose únicamente los góticos como los más perfectos dentro de la evolución de los estilos de la Edad Media. Es justamente el examen atento de los edificios lo que ha de conducir al debido aprecio del gótico y su dife- 
renciación respecto a los demás estilos medievales, pues ahora, salvo en Jovellanos, todo el arte medieval se ofrece como algo confuso y uniforme a pesar de su diversidad.

Así, para Ponz, todo el arte medieval es gótico, pues a esta arquitectura medieval la llamamos así "para distinguirla, sin otras señas, de la griega o románica» $(F ., \mathrm{I}, 4,2)$. De la misma manera, Bosarte, al hacer la relación de los edificios góticos segovianos, incluye todos los medievales, incluso la iglesia mudéjar del Corpus Christi y la iglesia de San Esteban, por ejemplo, con su pórtico lateral, «según la costumbre laudable en muchas iglesias góticas» (G., p. 50), pues, en efecto, para él,

"por estilo gótico o manera gótica de edificar se entiende comúnmente aquella que corre desde los tiempos de Carlo Magno hasta la restauración de las Artes en el siglo xvir $(I$, p. 7$)$.

aunque distingue cómo entre los siglos IX y XIII los edificios no eran muy grandes, ni muy adornados, "pero desde el siglo xIII en adelante se fueron haciendo edificios de mucha capacidad y adorno" ( $I$., p. 8).

Jovellanos distingue con claridad dos fases perfectamente diferenciadas. En la primera, que comprende desde principios del siglo viII hasta fines del siglo XII, se pueden distinguir

"dos especies de arquitectura: una la verdadera y propiamente arabesca... y otra, que yo llamaría con mucho gusto, y no sin buena razón, arquitectura asturiana, por el país en que principalmente se usó» (Q., ps. 378-379).

y aun al hablar de la Cámara Santa de Oviedo percibe que se parece «a otros monumentos de que hay abundancia en Asturias, y deben referirse a los siglos $\mathrm{IX}, \mathrm{X}$ y XI»,

y que por cierta relación que halla con los edificios árabes supone

"que los arquitectos de Asturias empleados en las obras de alguna entidad por aquellos tiempos, eran árabes también, o a lo menos discipulos de los árabes»(R.).

En la segunda fase del arte medieval se desarrolla la arquitectura llamada gótica, que

«tuvo de duración tres siglos. Nació en el siglo xvirI... y ahora podemos decir que acabó con el xv. Es verdad que hay fábricas insignes de este género trabajadas en el siglo XvI...»(Q.).

Dentro de lo asturiano comprende Jovellanos, por tanto, todos los estilos anteriores al siglo XII, excepto el visigodo, y así, por ejemplo, cuando examina la iglesia de San Vicente de la Barquera, que tiene dos portadas de tradición románica, escribe: «Grande iglesia, al parecer del 
siglo XII, de arquitectura asturiana y oriental, mixta», o, al referirse a la iglesia de Santillana del Mar: «...iglesia de arquitectura asturiana, que puede ser del siglo xiI» (M., p. 294), y al referirse a la iglesia mozárabe de San Millán de Suso escribe:

«La iglesia, de dos naves divididas por una serie de arcos, que me hizo recordar los de la iglesia verdaderamente gótica de Baños, por más que los arcos parezcan árabes» (P., p. 278).

La obsesión por hallar orígenes orientales a la arquitectura gótica, como el encontrar sus fuentes en la literal observación de la naturaleza, son aspectos de este incipiente romanticismo a todas luces evidente. Para Bosarte la destrucción de la arquitectura antigua por los bárbaros determina que se adoptasen las formas que los arquitectos persas habían comenzado a introducir en el Imperio de Oriente. En efecto, Carlomagno se inspira en las formas que sospecha Bosarte habian sido introducidos por Metrodoro, en tiempo de Constantino, y Esteban, en tiempo ya de Justiniano, los cuales inician el empleo del arco apuntado y los entrelazamientos. También introducen la afición a la forma apuntada de la pirámide, cuyo fundamento «está en las rocas y en las puntas, o cimas de las montañas» $(I)$, explicando Bosarte incluso los elementos salientes en las aristas de los remates piramidales como una traslación poética de las torres de triunfo orientales que se ornamentaban con las cabezas de los enemigos vencidos, lo que no obsta para que en otro lugar estime que el origen de toda la riquísima decoración gótica puede buscarse en las labores de pasamanería, de la misma manera que habían hecho los arquitectos árabes :

«...Los árabes... trasladaron la pasamanería a la Arquitectura... pareció bien esta ligereza y gallardia como pareció también a los Europeos en el tiempo que se fueron edificando todas esas Catedrales y Palacios que llaman del estylo gótico, que es un estilo meramente oriental» (L., p. 80).

También para Jovellanos la arquitectura gótica es de origen oriental, y así la denomina con frecuencia. Así, al referirse a la iglesia de Santiago de Bilbao, dice «gran templo gótico, o sea oriental» $\left(N_{.}\right.$, p. 26); pero analizando con más cuidado sus orígenes se inclina por la denominación de ultramarina, ya que estima que ha de buscarse su origen «en las expediciones que se conocen con el nombre de Guerra de Ultramar», por lo que estima más conveniente esta última denominación, que, de adoptarse,

«no sólo logrará desterrar un título tan extravagante como el que ahora tiene la arquitectura gótica, sino que le sustituirá otro digno de la aprobación de la Europa sabia» (U., p. 376). 
Pues, en efecto, en este ensayo sobre la arquitectura gótica, después de registrar el resurgir de esta arquitectura en Inglaterra y de analizar la tesis de Ferri, insiste en la impropiedad del nombre, máxime en Inglaterra, pues aun en España por ser godos los bárbaros podria justificarse, y nunca en Inglaterra, donde, introducida por los normandos, sería, a
lo sumo,

«un producto del capricho de los artistas y no de la imitación de ningún sistema que se pueda llamar gótico» (U., p. 373).

Realmente Jovellanos estima que, como queda dicho, su origen está en función de la Guerra de Ultramar, pues hay que tener presente que esta arquitectura

"apareció de repente y casi a un mismo tiempo en toda Europa, y... apareció ya en su mayor pompa y perfección» (Q.),

por lo que hay que descartar que sea el fruto de una evolución del arte occidental. Por eso supone que los cruzados llevaron arquitectos, que no sólo se ocuparon

"en levantar máquinas militares, sino también en la reparación y fundación de las ciudades y poblaciones que hubieron de construir mientras duró su dominación» (Q.),

para lo que se inspiraron tanto en las construcciones orientales como en la forma de las propias máquinas militares, por lo que es

"verosímil y probable que el modo de edificar llamado gótico o tudesco vino del Oriente a Europa, traído por los ingenieros y arquitectos que pasaron con los cruzados» (Q.).

Así, pues, en los edificios "griegos, árabes y egipcios existentes en el Oriente por los siglos XI, XII y XIII, en que se hizo la guerra santa», es donde está la fuente de la arquitectura gótica (Q.), que, como queda dicho, se mezcla con elementos tomados de la arquitectura militar, así en las altas torres en forma piramidal, tomadas de las torres militares con los cadalsos para los vigías, por ejemplo. Aunque a veces es el propio capricho del arquitecto, como cree que debe de ocurrir respecto a la proliferación de torres:

«Ellas son, así como la más noble, la menos necesaria, o por mejor decir, la más inútil parte de los edificios sagrados. ¿De qué sirven en nuestras catedrales estas moles altísimas, tan dispendiosas, tan arriesgadas y multiplicadas tan en vano? Diráse que de puro ornamento, y así lo creemos..." (Q.).

Y analizando los elementos ve el origen egipcio del arco apuntado, y árabe de los arcos dobles y triples como de las labores menudas de entre- 
lazos como apunta la posibilidad del origen pérsico de los elementos humanos incorporados a la arquitectura, y no se atreve a seguir a Bosarte en la hipótesis respecto al origen en las torres triunfales orientales, "donde clavaban o colgaban las cabezas de los enemigos", para explicarse los elementos salientes en las aristas de los remates piramidales góticos. Todo lo cual no obsta para que en sus cartas a Ponz escriba: «creo que la arquitectura gótica es hija de la morisca y nieta de la griega» $(R$.), estimando que bien los alemanes «o bien otros europeos, pues esto no está averiguado», tomaron de los árabes su modo de edificar, los cuales a su vez lo habían tomado, desvirtuándolo, de la arquitectura griega o bizantina.

Como queda dicho, dentro de la línea de estos intentos raciunales de explicación de la arquitectura gótica son dos aspectos los que por cima de todos sobresalen. De un lado la belleza inexplicable, casi misteriosa, que producen los edificios góticos; de otro, el poder de evocación que suscitan. Los textos de Capmany, Jovellanos, Bosarte y Ponz son suficientemente explícitos, lo cual en cierto modo, por su subjetivismo, enlazan con la iniciación del aprecio por lo "pintoresco" que recoge Jovellanos. Comentando a William Gilpin, Jovellanos explica cómo conforme a este nuevo método todo

«cuanto la vista descubre de sublime y raro por su belleza, su gracia, o bien por su misma horridez, todo se ha descrito y grabado y publicadon.

De este concepto de valorizar lo pintoresco, surge el tipo de jardín inglés que comenta Jovellanos, en el que se reúnen los objetos más diversos con un fin, $y$

«este fin es tan nuevo como noble y digno del ingenio humano, porque es del todo sentimental. No se trata en éstos como en los jardines comunes, de recrear solamente la vista, sino también de recrear el corazón»,

por lo que se procura suscitar la alegría, la meditación, la sorpresa, la melancolía en fin, para que

«recorriendo las varias avenidas de estos jardines, ora presentan escenas bucólicas con sus pastores y rebaños..., ora la de un bosque um. brí, que la ruina de algún monasterio o iglesia gótica, y los trozos de su cementerio y sepulcro y ancianos cipreses hacen más melancólico. Ya... los restos de algún viejo castillo con sus muros y torreones, medio desmoronados, despiertan la memoria de los tiempos caballerescos; o ya... las augustas reliquias de un templo griego..., la ermita solitaria de un anacoreta.... (U., ps. 377-378). 
Es esta exaltación sentimental, prerromántica, este poder de evocación, el que particularmente acompaña a esta arquitectura y que inclusive es percibida por el propio Bosarte, a pesar de que lo atribuye a defecto :

«Un cierto ayre de magestad acompaña a muchas Iglesias de estilo gótico..., pero esta magestad triste y adormecida, como la del ciprés en el jardín, depende de un defecto y no de alguna qualidad excelente... son más altas de techos de lo que debían ser..., pues en esa proceridad y altura consiste ese ayre de magestad melancólica, que a muchos agrada... Si se rebaxan un poco las bóvedas, desaparecerá esa magestad, sin mutación alguna en el estilo" $(I$.$) .$

Claro es que es Jovellanos quien mejor representa esta tendencia, y ya su evocación es una vaga añoranza de los tiempos medievales, como en la deliciosa descripción del castillo de Bellver, o la descripción literaria, como una estampa, de la catedral de Palma:

«...Descuella majestuosamente la iglesia catedral... aparece entre Ios demás edificios como una grande almiranta en medio de pequeñas corbetas y faluchos...» $(T$, p. 360$)$,

por lo que, al valorar la acción de la «facultad sentimental de nuestra alma», se sitúa ya claramente en una actitud romántica, en la que se admiran «los nobles siglos caballerescos» y se evalúa el efecto que enriquece la apreciación estética y sentimental de los edificios ruinosos cuando se observan a la luz crepuscular. Y así escribe:

«...No puedo dejar de creer que... las relaciones que hay entre... la arquitectura... y la facultad sentimental de nuestra alma, no puede dejar de influir considerablemente en el adelantamiento de las artes inglesas, y señaladamente de la de edificar» $(U$., p. 379);

$\mathrm{y}$, en otro lugar, escribe:

"Alguna vez, al volver de mis paseos solitarios, mirándole, a la dudosa luz del crepúsculo, cortar el altísimo horizonte, se me figura ver un castillo encantado, salido de repente de las entrañas de la tierra" (S.).

Otro claro indicio de esta actitud estimativa respecto a la arquitectura medieval está en la insistencia con que se insiste en la conveniencia de mantener los edificios tal como están, sin intentar desfigurarlos o desvirtuarlos con adiciones o reformas. Actitud conservadora que contrasta fuertemente con la que se adopta frente al barroco. Así Ponz, cuando se refiere a los proyectos de renovación de la catedral de Valencia, recomienda toda cautela:

«Gran ocasión para dejar una memoria inmortal, si tan importante idea se lleva a efecto con toda la cautela necesaria en la elección de hábil profesor..." $(F$., IV, 2, 43). 
Bosarte es más radical que Ponz en este sentido, y así, cuando en Segovia ve una imagen de la Virgen «de tan feliz execución que la cabeza es poco menor que el cuerpo», recomienda que estas obras

«de la decrépita edad de las artes, no se rompan ni se destruyan por desprecio, sino, al contrario, que se conserven donde no hagan estorbo; pues estos monumentos sirven de testimonio para la historia de las $\operatorname{artes} \ldots{ }^{\prime}(G$, ps. 4445).

Criterio de conservación que repite al observar lo ocurrido con la fachada renovada del Colegio de Santa Cruz de Valladolid, pues

«la nobleza se hace consistir en la antigüedad. Barbarie es pintar la piedra; pero aún más barbarie es raerla... Por mi dictamen ningún vejestorio debe renovarse. Hágase de nuevo quanto se quiera; pero lo viejo debe quedar ileso para llevar el hilo de la historia en las producciones de las artes» (G., p. 107).

Aún con mayor claridad se expresa cuando observa la lamentable renovación de la facha principal de la catedral de Burgos:

«Las puertas de la fachada principal se ven desposeídas de sus adornos primitivos. Mal consejo...; los adornos de estilo gótico no deben picarse ni raerse, pues con semejante operación se defrauda a la historia del arte de sus testimonios auténticos, que son la existencia misma del cuerpo de sus obras...» (G., ps. 259-264).

$\mathrm{Y}$ otras veces se lamenta simplemente de la desaparición por abandono de estos edificios medievales: "Sería lástima que acabase de perecer una antigualla tan apreciable", dice respecto al patio de Alfonso VIII de las Huelgas (G., p. 260), o a manos de la acción de los jóvenes fundibularios, que juegan con sus hondas lanzando las piedras sobre las esculturas de las fachadas, pues

«entre nosotros cada muchacho es un godo en las cosas que puede haber a la mano, y un fundibulario bien exercitado en las que su espiritu destructor necesita la piedra arrojadiza» (G., p. 305),

abogando incluso por la limpieza de las iglesias medievales del blanqueo general a que fueron sometidas, pues

«lo que debería hacerse sin dilación para redimirse de nota tan grosera es fregar y limpiar con mucho aseo la obra de piedra...» (G., p. 59).

Todo lo cual no obsta, en este característico vaivén del pensamiento en momentos de crisis, para que en su "Disertación sobre el estilo gótico", si bien mantiene el criterio de que las obras no deben corregirse, ni enmendarse, pues

«un edificio, u otra obra del Arte tiene un cierto derecho a existir. Las correcciones y las enmiendas de otras escuelas no le pertenecen. Ni las 
pinturas se han de retocar como quiere el vulgo; ni las arquitecturas se han de alterar, como zelosamente quieren los profesores eruditos... (I., ps. 52-53),

diga, unas líneas antes, como hemos indicado anteriormente, que las añadiduras grecorromanas a las obras góticas no pueden perjudicarlas, y que en su "Viaje artístico» indique que «la mezcla y confusión de estilos es intolerable» y que «la obra vieja se debe continuar según su estilo» (G., p. 264). ${ }^{15}$

Como es lógico, el espíritu más avanzado de Jovellanò aboga también por la conservación de todas las obras medievales. Así, respecto a las arquetas de San Millán y San Felices, exclama: "¡Qué monumentos para la historia de las artes! ¡Qué dignos de ser conservados, y mucho más de ser publicados!» ( $P$., pág. 280), como lo mismo propugna, por ejemplo, ante el estado de destrucción del castillo de Bellver.

En contraste con estos criterios, los adjetivos peyorativos se acumulan al hablar de los edificios barrocos. Es sabida y muy conocida la acre y beligerante actitud de Ponz a este respecto. No lo es menos Bosarte:

"Aquella máxima proverbial tan arraigada en el baxo vulgo; que sobre gusto no hay disputa, ha venido a parir estos monstruos, que se han procurado exterminar a voces y gritos: el churriguerismo y el chinesco» (G., p. 60),

y en su ensayo sobre el gótico cree necesario estudiar los orígenes y la razón del gótico medieval,

"principalmente para precaver el progreso que ha hecho la plaga pestilente de otro gótico moderno distinto del antiguo, que en nuestro tiempo ha estragado y corrompido el aspecto de las obras de Arquitectura en sus adornos, como en el de los muebles y alhajas...» (I., p. 11),

pasando seguidamente a detallar las «especies» de ese gótico moderno.

En realidad, como decíamos al principio, la crítica respecto al gótico en cuanto se opone al arte clásico es mínima, pues se estima como algo vivo que tiene su campo de acción fundamentalmente en el campo de la arquitectura religiosa, en la que se encuentran abundantes ejemplos dignos de ser imitados.

Es evidente, al mismo tiempo, que se percibe la necesidad de buscar un camino que conduzca a su mejor conocimiento como un sistema or-

15. En este lugar escribe: «En suma, la regla sana que los casos dudosos de continuación y reparación de obras considerables puede tomarse es ésta: La obra vieja se debe continuar según su estilo. La obra nueva subsistente por sí no está sujeta al estilo antiguo. La mezcla y confusión de estilos es intolerable, y ninguna obra vieja debe picarse ni acomodarse a otro estilo opuesto.» 
gánico, con lo que se prepara el camino para los estudios del sistema que rige a la arquitectura gótica. Ya el propio Bosarte tuvo intuición de su existencia, y esto le lleva a afirmar que sla arquitectura gótica es un sistema entero, aunque heterodoxo; opuesto en todo al sistema de la antiguiedad griego-romana» (G., p. 72). A esta conclusión llega fundamentalmente por el análisis y la vista de los planos de la iglesia de la Magdalena de Valladolid, por lo que escribe:

"Comúnmente se cree que el estilo gótico en la arquitectura es enteramente arbitrario, y que en sus obras no hay sistema arreglado, y que cada arquitecto gótico subía o bajaba, alargaba o acortaba, disminuía o aumentaba según su capricho..., dexando como es razón a la arquitectura antigua todas sus prerrogativas... una obra gótica... la parroquial de la Magdalena, puede servir de prueba de que los góticos no eran tan arbitrarios como se les hace... hallamos medidas prescritas por el arquitecto...» (G., p. 104).

Este giro en la apreciación de la arquitectura gótica induce, como es lógico, a profundizar en la razón y evolución del estilo, lo cual ha de conducir, en el siglo XIX a los trabajos que fijan sus características, permitiendo la imitación. Y, al igual que en la arquitectura, en las artes figurativas, aconseja Bosarte:

«observar hasta qué punto llegaron sus autores, qué extensión tuvieron sus conocimientos, qué géneros fueron los que más frecuentaron, y aun otras curiosidades que tienen relación con el progreso y decadencia de las ideas del ingenio artista» (G., p. 270),

todo lo cual ha de conducir forzosamente a un conocimiento más profundo del arte medieval.

Vemos así, en resumen, cómo en pleno desarrollo de las teorías neoclásicas, cuando en España comienzan a practicarse a impulsos de la Real Academia, ya se advierte el inicio de la admiración y aprecio del arte medieval, que ha de ser una de las características más distintivas del período romántico. 